\title{
INDONESIAN LANGUAGE ASSISTANT PROGRAM IN AUSTRALIAN SCHOOLS: RECRUITMENT AND SELECTION PROCESS
}

\author{
Tri Indri Hardini*, Sri Setyarini, Sri Harto \\ Universitas Pendidikan Indonesia \\ *e-mail: tihardini@upi.edu
}

\begin{abstract}
This research aims to investigate the process of recruitment, selection, and implementation of the Indonesian language assistant program of the Universitas Pendidikan Indonesia (UPI) in Australian schools. The main purpose of this research is to find out the processing stages and to see strengths and weaknesses in each stage of the recruitment and selection process held at UPI. The data were collected through survey questionnaires, in-depth interviews, and documents of the Indonesian language assistants on the implementation of the program. The questionnaires and interviews were directed to the members of recruitment and selection team, alumni, and candidates of the Indonesian language assistants. A descriptive qualitative method was applied to explore and analyze the activities of the language assistants' candidates and alumni in each of the overall stage processes. The results show that there are some stages of recruitment and selection process, which are then described in a figural process. The recruitment covered the submission of a curriculum vitae completed by relevant administrative documents to qualify for registering the program. The selection process required skills and competences of the candidates in Indonesian language, English, Indonesian and Australian cultural knowledge and skills and self-management. Accordingly, a system development for recruitment and selection process to result in more competent candidates for the Indonesian language assistants is urgently needed to elaborate the whole process in efficient manner.
\end{abstract}

\section{Keywords: Indonesian language assistants, recruitment, selection}

\section{PROGRAM GURU BANTU BAHASA INDONESIA UNTUK SEKOLAH-SEKOLAH DI AUSTRALIA: PROSES REKRUTMEN DAN SELEKSI}

\begin{abstract}
Abstrak: Penelitian ini bertujuan untuk mengungkap sistem proses rekrutmen, seleksi, dan implementasi program penyelenggaraan guru bantu Universitas Pendidikan Indonesia (UPI) di beberapa sekolah di Australia. Tujuan utama dari penelitian ini adalah untuk menelisik tahapan proses dan menemukan kelebihan dan kekurangan setiap tahapan sistem proses rekrutmen dan seleksi yang dilaksanakan di UPI. Data penelitian dikumpulkan melalui angket, wawancara mendalam, dan dokumen terkait pelaksanaan program guru bantu. Kuesioner dan wawancara ditujukan kepada anggota tim seleksi dan alumni serta calon guru bantu. Pendekatan deskriptif-kualitatif diterapkan pada penelitian ini untuk menggali dan menganalisa secara mendalam kegiatan-kegiatan calon dan alumni guru bantu dalam setiap tahapan proses. Hasil penelitian menunjukkan bahwa ada beberapa tahapan proses rekrutmen dan seleksi, selanjutnya akan digambarkan dalam bagan tahapan proses. Tahapan rekrutmen meliputi pengumpulan data diri yang dilengkapi dengan beberapa dokumen terkait untuk memenuhi persyaratan pendaftaran program. Proses seleksi mensyaratkan para calon untuk memiliki keterampilan dan kompetensi antara lain kemampuan bahasa Indonesia, bahasa Inggris, pengetahuan dan keterampilan budaya Indonesia dan Australia, dan manajemen diri. Oleh karena itu, pengembangan sistem rekrutmen dan seleksi untuk menghasilkan calon guru bantu bahasa Indonesia yang lebih kompeten sangat diperlukan untuk merinci seluruh proses dengan efisien.
\end{abstract}

Kata Kunci: guru bantu bahasa Indonesia, rekrutmen, seleksi

\section{INTRODUCTION}

The Teaching of Indonesian to Speakers of Other Languages (TISOL) has been quite popular in some countries in the world. The practices of TISOL in these countries aim to follow up one of the Government to Government ( $G$ to $G)$ programs both in bilateral and in multilateral cooperations. These practices do not 
only intend to introduce Indonesian language to foreign speakers but also build cultural ties for mutual understanding among countries in the international level. The TISOL practices have long been implemented both at home and overseas. In Indonesia, TISOL is held in some reputed higher education institutions including public and private universities.

The Government of the Republic of Indonesia through the Bureau of Planning and International Cooperation, the Ministry of Education and Culture (MoEC) assigns approximately 45 prominent universities to hold TISOL through a scholarship program called Darmasiswa (Muliastuti, 2016). The scholarship is provided to prospective students coming from various countries all over the world to study Indonesian language and cultures in the Indonesian universities. In addition, according to the Language Development and Fostering Agency in Jakarta, TISOL has also been held by 46 countries both at higher education institutions and at embassies and consulates of the Republic of Indonesia in various countries (Azizah, Widodo, \& Lestari, 2012). Moreover, there are at least 179 centres for TISOL in 48 countries (Maryani, 2011; cited in Sujana, 2012) and it has even been formally taught in 72 countries all over the world (Sari, Sutama, \& Utama, 2016; cited in Gusnawaty \& Nurwati, 2019) and this number will always be increasing.

Some factors have been identified to have contributed to the development of TISOL at home and overseas, among others, are: geographical location, trade and industry, tourism, and education. For instance, Indonesian in which its country is geographically close to Australia has been primarily chosen by Australian school students and other relevant individuals to study for some reasons, i.e. vacation, business, and other related activities (Sujana, 2012). Also, through the implementation of the ASEAN Economic Community (AEC), foreign countries, particularly neighbouring countries in the region are free to share goods, exchange services, invest capitals, and send experts to Indonesia (Saputro \& Arikunto, 2018) and the AEC even brings valuable attractions for foreign workers to do their business in Indonesia (Mediyawati, Lustyantie, \& Emzir, 2019).

This condition requires the importance of Indonesian language mastery for those who share their interest to do various businesses in Indonesia (Saputro \& Arikunto, 2018). Then, there is a tendency for the young South Koreans nowadays, for example, to study Indonesian language and cultures in various universities in Indonesia and there at least three universities in Korea that are now opening Indonesian language studies in their universities (Hyun, 2015). Indonesia is chosen by Korea since it has a very strategic geographical position in South East Asian countries. In addition, many of young South Koreans studying Indonesian language and cultures are considering the rapid growth of the Indonesian economic development in which "the annual growth of the economic development in Indonesia reached $6.2 \%$ in $2010,6.5 \%$ in 2011 , $6.3 \%$ in 2012, and 5.8\% in 2013. Meanwhile, the South Korean economic growth reached $6.5 \%$ in $2010,3.7 \%$ in $2011,2.3 \%$ in 2012 , and $3.0 \%$ in 2013" (Hyun, 2015: 13).

In compliance with the rapid growth of learners of Indonesian as a Foreign Language (IFL) which is popularly known as Bahasa Indonesia bagi Penutur Asing (BIPA), as a higher institution which focuses its core mission on education, Universitas Pendidikan Indonesia (UPI) has been mandated by MoEC to run the TISOL through various programs, i.e. Darmasiswa Scholarships, Developing Countries Partnerships Scholarships, Association of South East Asian Nations (ASEAN) International Mobility for Students (AIMS), and South East Asian (SEA) Teacher Partnerships to mention just a few. These programs have attracted foreign students from different countries to study Indonesian language and cultures spread out in different faculties, students' units, and in the UPI's language centre. In addition, some of the programs require the teachers to teach Indonesian language and cultures at partnering schools, colleges and or universities overseas.

One of the programs, for instance, is a collaborative program between UPI and the Department of Education and Training (DET), Victoria, Australia for the provision of Indonesian language assistants to work in various primary and secondary schools in Victoria, Australia for a year. The program aims to introduce Indonesian language and cultures to all levels of Victorian students from primary to secondary schools. As a native speaker with a language education background, the main task of the 
language assistants is to support local teachers in carrying out the teaching of Indonesian language and cultures. The activities carried out by the language assistants include teaching both in teams and in small groups and providing language services to individual students through face to face in language classes and through online services under the coordination of local teachers (DET, 2018).

According to the Department of Education, Employment and Workplace Relations (DEEWR, 2010), Government of Australia, there were 191,316 students $(5.6 \%)$ of the total national student population studied Indonesian in Australian primary and secondary schools the third most studied language in Australian schools in 2008. The Language Assistants Program (LAP) has long been run by the Department of Education and Training, Victoria, Australia in collaboration with various countries, i.e. France, Germany, Indonesia and Spain, to provide language support teachers at Victorian government schools. The program places at least 24 graduates from various countries of origin to accompany the local teachers to teach the mother tongue to Australian students at various levels (DET, 2018). Then, during his last official visit to UPI on July 26, 2017, the Executive Director of International Education Division, DET, Victoria, Joel Backwell, updated the data of the Indonesian language learners in Victorian schools reaching up to approximately 50,000 students in primary schools, 12,000 students in junior high schools, and 3,000 students in senior high schools.

The number of Indonesian learners in Victoria has now put the Indonesian language ranks four (Dodiangga, 2017) after Mandarin, Chinese, and Italian and it has been taught in 500 schools and it becomes the fourth most popular language in Australia (Andayani, 2016; cited in Gusnawaty \& Nurwati, 2019). In addition, Backwell also shared some new views on the strategies to improve the quality of bilateral relationships between Australia and Indonesia in general and Australian schools and UPI in particular. These strategies were focused on creative thinking, problem solving, ethical understanding, interpersonal, and intercultural capabilities (national curriculum) which were believed to increase the number of students in Victoria, Australia to study Indonesian language and cultures (Dodiangga, 2017).
In response to the challenges of the LAP funded by DET, UPI which is then represented by the Faculty of Language and Literature Education hereinafter referred to as Fakultas Pendidikan Bahasa dan Sastra (FPBS) is responsible to see and find out whether or not its fresh graduates selected to participate in the Indonesian language assistants program in Victoria, Australia are showing their best performance to fulfill the competences required by both UPI and DET. In addition to show their extensive cross-cultural knowledge reflected from their active responses to the development of science and technology, the language assistants (BIPA teachers) are also required to show their social, pedagogic, professional, and personality competences (Sujana, 2012). It is also in line with Suyitno (2007) indicating that BIPA teachers do not only teach Indonesian language but also introduce Indonesian cultures closer to foreign learners. Other responses to the challenges of BIPA teachers to improve their teaching quality were also made by Idris (1999) giving emphasis on the processes rather than results particularly with regard to the selection of learning materials, teaching techniques, assessment and evaluation. Meanwhile, Azizah, et. al. (2012) strongly advise the involvement of experts as resource persons or as referents to solve problems both in linguistic and in non-linguistic aspects, including issues in BIPA management. The issues were then identified by Nugraheni (2015) requiring comprehensive national policies in some aspects, i.e. curriculum, teaching materials, teachers, and supporting facilities. The other issue was shared by Gajewski (2018) highlighting the importance of understanding learners' needs and skills considering that they learn Indonesian language for different purposes, i.e. tourism, communication with local people, and business relationships.

With regard to the complex challenges faced by BIPA teachers, therefore, the selection process to recruit the BIPA teachers, in which, in Australian context they are called Indonesian language assistants, is then considered crucial since this is the initial key stage to get the right candidates who can minimize potential problems that might be encountered by the selected candidates when dealing with their professional duties as Indonesian language assistants in Australian schools. These aspects, 
i.e. recruitment and selection process are worth taking into serious consideration by FPBS UPI since they are key stages to maintain the quality and the sustainability of the Indonesian language assistants program. The success of these aspects in BIPA program in this particular collaboration between UPI and DET, Victoria, Australia is expected to come up with a model which can then be implemented for further development in other partnering countries. For the above reasons, this phenomenon is worth investigating to provide a response to the future challenges encountered by the BIPA teachers to struggle taking the Indonesian language to go international. However, in this particular research, the focus is then limited to the recruitment and selection process by identifying the strengths and weaknesses in each stage of the processing system to come up with more competent candidates to select in the Indonesian language assistants program.

\section{METHODS}

In this study, the researchers interact and collaborate with several parties such as assessors of the selection process, experts in relevant fields, participants of the Indonesian language assistant program, and alumni of language assistants program to obtain the data needed to answer the research questions.

This research is focused on identifying the internal processes at UPI with regard to recruitment and selection process to identify candidates' skills and competences required for the language assistants to carry out their duties as Indonesian language assistants in Victorian schools, Australia. The investigation on both recruitment and selection processes and the required skills and competences to qualify for the BIPA teachers is viewed from a variety of perspectives including team of assessors for the selection process, selected participants as the candidates of the Indonesian LAP and initial information on these related aspects. Thus, the information on the skills and competencies needed by the Indonesian LAP could be holistically obtained from these parties and resources.

Three experts from different fields, one was representating the Faculty of Language and Literature Education (FPBS), another was a BIPA expert, and the other one was an expert in English language, were assigned by UPI to do the recruitment and selection process. The alumni and candidates of the Indonesian LAP were purposively selected to get involved in this study. The data were collected through survey questionnaires, in-depth interviews (Creswell \& Poth, 2018) and documents (Gay, Mills \& Airasian, 2006) of the language assistants on the implementation and completion of their program to explore their real skills and experiences in duties related to the internal process of recruitment and selection.

The survey questionnaires were distributed to 46 alumni of the Indonesian language assistants who had completed their duties in Victoria, Australia. The questions were exploring the suitability and relevancy of questions raised by interviewers in the process of selection and the actual conditions of works faced by the Indonesian language assistants when they were still in duties. These were intended to see benefits and explore significances of questions raised by the interviewers in the recruitment and selection processes. First, a commitment of the language assistants in their actual experiences related to the implementation of their works. Second, the importance of creativity in producing teaching materials, selecting relevant teaching aids and media, and evaluating on the students' learning achievement. Third, the importance of prior teaching experiences for the implementation of working practices. Fourth, the assistants' communication skills with students, other teachers, school principals, and parents. Fifth, the importance of Indonesian cultural knowledge and skills in the contextual teaching practices in their Indonesian classes in Victorian schools.

The interviews were also done to nine alumni and eight candidates of the Indonesian language assistants purposively selected to explore information on the language assistants' actual experiences in the teaching and learning processes, activities followed by them during the program implementation, and problems encountered by the assistants and their ways out to solve the problems. Then, the documents of language assistants reported to UPI through the Office of International Education and Relations (OIER, 2011-2018) were explored to crosscheck the information provided by the language assistants during interview sessions and the ones written in the university official reports. These documents were also aimed at completing the 
missing information which was not provided by the language assistants in the interview sessions.

The data collected from the survey questionnaires, interviews, and documents of the Indonesian language assistants were then coded, classified, and then analyzed to see their similarities and differences to come up with common practices related with the aspects being investigated. The conclusions were then drawn from the research findings and from the results of the data analysis.

\section{RESULTS AND DISCUSSION Results}

In general, the results of this research highlighted some common practices in the implementation of bilateral cooperation between UPI and DET in the provision of the Indonesian language assistants program and, in particular, these addressed the main points related to the recruitment and selection process of the Indonesian language assistants managed by Universitas Pendidikan Indonesia (UPI) to work in Victorian schools, Australia and then described the skills and competences required by both UPI and DET, Victoria, Australia to qualify for the candidacy of the Indonesian language assistant program.

The Indonesian language assistant program itself was formerly initiated in 2004 through a collaboration of three parties involving Universitas Pendidikan Indonesia (UPI), Indonesia, Monash University, Australia, and the Department of Education and Training (DET), Victoria, Australia by signing a Memorandum of Understanding (MoU) in 2004 on the provision of the Indonesian language assistants to work with local teachers in primary and secondary schools in Victoria, Australia. At the early stage, the implementation of the program did not work due to some reasons, i.e. unclear information on the details of the program and of the candidates required for the program, insufficient information on the processes of visa for applicants, and lack of information on the schools assigned to host the Indonesian language assistants. Although the collaboration on the provision of the Indonesian language assistants had not shown any significant results as expected by the parties, the collaboration was continued for the following years through the signing of the following $\mathrm{MoU}$ in 2010.
Through quite intensive discussion among the three parties, better understanding on the roles of the parties came up. UPI provided the language assistants through internal selection processes to select the best candidates based on the quota determined by the Department of Education and Early Childhood Development (DEECD, formerly DET) and held a pre-departure training for the selected candidates prior to their departure to Victoria. Monash University played roles to provide some professional development through relevant education and training to the selected personnel. Then, DEECD was responsible to coordinate schools requesting the Indonesian language assistants in Victorian primary and secondary schools and provided them with the montly salary. Through such an intensive communication, based on the consultation with DEECD Victoria that time, UPI started to recruit six candidates in 2010 and they started their duties in office in 2011.

This success story was then continued in the following years. Six candidates were selected in 2011 and they started their official duties in Victoria in 2012. In the following two years, in 2013 and in 2014 consecutively, there were only two candidates selected in each year due to a decrease of quota from DEECD. Three candidates were then selected in 2015. In the following three years from 2016, 2017 to 2018, nine Indonesian language assistants were selected in each consecutive year. In addition, the other thing to note here is that there was an extension of MoU between UPI and DET in 2017. Finally, eight Indonesian language assistants are now local teachers in Victoria until the end of 2019. The following is the data of the Indonesian language assistants from UPI who worked in Victoria, Australia in the last eight years from 2011 to 2018 (OIER, 2011-2018) and those who are now working as the assistants in 2019 (Figure 1).

In accordance with the data on the UPI's Indonesian language assistants working in Victorian schools, Australia from 2011 to 2019, the assistants were placed in different schools with different number of schools to employ. For instance, among the nine alumni who had just completed their official duties as Indonesian language assistants in 2018, each one of them experienced to have worked together with two 


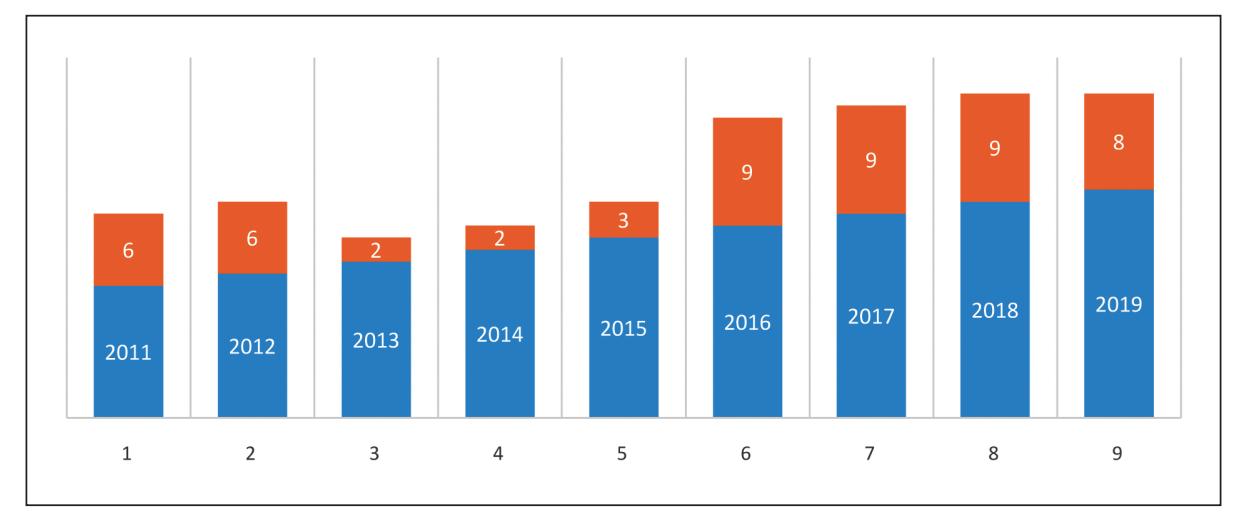

Figure 1. The Indonesian Language Assistants from UPI to Victoria, Australia (2011-2019)

different schools, one worked in one school, and the other one worked in three different schools within a year based on their communication with DET and schools. However, the schools were mostly located in the same area. Among the nine assistants, for instance, one experienced to work in only one school, Benalla P-12 College, in the area of Benalla. In addition, one of the assistants worked in three different schools, i.e. Lara Secondary College, Lara Primary School, Little River Primary School, however, they were also located in the same area, i.e. Lara. The rest of them worked in two different schools which were mostly located in the same areas, i.e. Alexandra, Ringwood, Warnambool, Dromana, Eltham, Bendigo, and Cobden. The details of the schools employing the Indonesian language assistants and the areas where the schools were located in the year 2018 are indicated in Table 1.

\section{Recruitment and selection process}

The recruitment and selection process started from the registration of the participants through the submission of administrative matters, completion of registration form, inclusion of a personal statement, and submission of reference letters. The administrative matters consist of the candidates' qualifications, i.e. fresh graduates from the undergraduate program of the Faculty of Language and Literature Education of the Universitas Pendidikan Indonesia (UPI), with no more than one year of teaching experiences, availability to take part in the world of education at UPI after the completion of their program in Victoria, Australia, the candidates' commitment

Table 1. Schools Employing the UPI's Language Assistants (2018)

\begin{tabular}{|c|c|c|c|}
\hline No. & No. of Assistant & Area & Schools \\
\hline 1 & 1 & Alexandra & $\begin{array}{l}\text { 1. Alexandra Secondary College } \\
\text { 2. Marysville Primary School }\end{array}$ \\
\hline 2 & 1 & Benalla & 1. Benalla P-12 College \\
\hline 3 & 1 & Ringwood & $\begin{array}{l}\text { 1. Ringwood Secondary College } \\
\text { 2. Ringwood North Primary School }\end{array}$ \\
\hline 4 & 1 & Warrnambool & $\begin{array}{l}\text { 1. Warrnambool East Primary School } \\
\text { 2. Warrnambool College }\end{array}$ \\
\hline 5 & 1 & Dromana & $\begin{array}{l}\text { 1. Dromana Secondary School } \\
\text { 2. Rye Primary School }\end{array}$ \\
\hline 6 & 1 & Eltham & $\begin{array}{l}\text { 1. Bendigo South East Secondary } \\
\text { 2. Eaglehawk Secondary College }\end{array}$ \\
\hline 7 & 1 & Bendigo & $\begin{array}{l}\text { 1. Bendigo South East Secondary } \\
\text { 2. Eaglehawk Secondary College }\end{array}$ \\
\hline 8 & 1 & Cobden & $\begin{array}{l}\text { 1. Cobden Technical School } \\
\text { 2. Cobden Primary School }\end{array}$ \\
\hline 9 & 1 & Lara & $\begin{array}{l}\text { 1. Lara Secondary College } \\
\text { 2. Lara Primary School } \\
\text { 3. Little River Primary School }\end{array}$ \\
\hline
\end{tabular}


to carry out duties during their carrier as Indonesian language assistants in Australia. In addition, the applicants of the program were also required to submit an official application letter completed by legalized copies of diploma and academic transcript, a curriculum vitae, and a recent passport sized photograph.

The registration form was the form that should be completed by individual language assistant and then sent it to DET to prepare for the invitation letter as one of the requirements to apply for the visa. The personal statement was a statement of the candidate's ideas with regard to the implementation of his or her work in the assigned schools and the personal ideas related to future employment after coming back from Australia and completing his or her duties as an Indonesian language assistant. The personal statement was also completed by two reference letters from the related parties who are considered relevant with his or her candidacy.

The completion of the administrative matters was then continued to the presentation session, interview session, and announcement of the selected candidates. The presentation session tried to identify the candidate's qualifications, skills, and competences in the Indonesian language for foreigners as a BIPA teacher. In addition, the candidate has to show his or her English proficiency as required by the targeted country, Australia. Then, the candidate was also required to have cultural knowledge and skills of the Indonesian arts and cultures and to have the cultural knowledge and skills of the targeted country. After the completion of the presentation, the interview sessions were done to explore the candidates' understanding on the conceptual framework of the language assistants program and the candidate's motivation and commitment to undertake the program in the targeted country and the individual candidate was supposed to be responsible for some financial matters, i.e. a return ticket Indonesia-Australia, expenses for passports and visa, and other fees for the arrangement of health insurance. Also, they were supposed to get ready to be placed in the areas of hundred kilometer away from the city of Melbourne, Australia. The selection team members had to provide a description on candidates' assessment results and give a score ranging from one to 10 to each of the contestants. When the participants were selected as the candidates, they had to provide relevant documents for visa applications and attended internal pre-departure training organized by UPI before their departure to Victoria. Clear descriptions on the recruitment and selection process can be described in Figure 2.

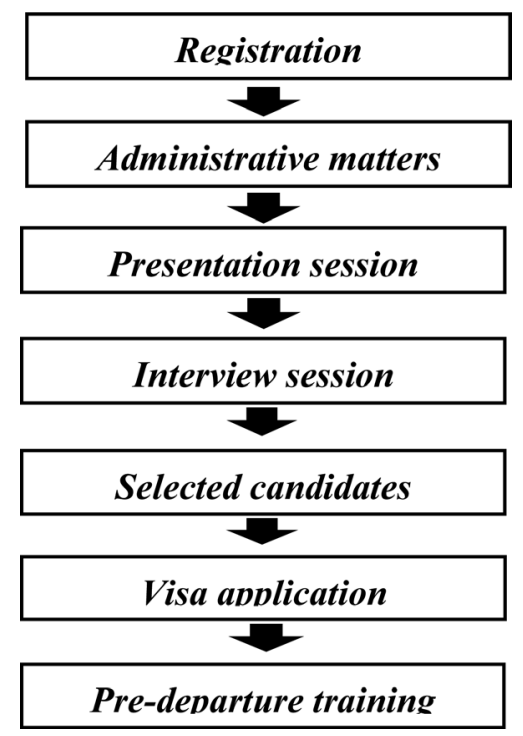

Figure 2. Recruitment and Selection Process

\section{Skills and Competences required for Indonesian language assistants}

The competences and skills of BIPA teachers required by DET were those identified to show their backgrounds as native speakers of Indonesian who recently graduated from relevant education studies of the undergraduate program, they were proficient in English, and they were ready to be placed in selected schools for up to 12 months in Victoria, Australia. They shared their contemporary knowledge of Indonesian language and cultures, they could improve the teachers and students' confidence and fluency in Indonesian language, and promoted an understanding of the Indonesian language and cultures to the school community (DET, 2018).

In the Regulation of the Minister of National Education number 16 year 2007 concerning Academic Qualification Standards and Teacher Competence, it is stated that the teacher competence consists of four domains of competency, i.e. pedagogic competence, personality competence, social competence, and professional competence. These four competences are closely related with the teachers supporting knowledge to implement their teaching practices inside and outside the 
classrooms. Then, according to Law number 14 year 2015 in Article 1 (paragraph 1), the main task of the teacher is to educate, teach, guide, direct, train, assess, and evaluate students. Given the complex tasks of the teacher, a number of competences are needed to implement them as part of the teaching profession. In accordance with the above competences and skills required for the program, Respondent-6 (hereinafter referred to as R6) in a questionnaire, for instance, shared her idea, "We are placed in formal schools assisting the local teachers, however, in some occasions, we are given chances to teach the students with their supervision. Therefore, the skills and competences as the Indonesian language assistants must be mastered comprehensively (Questionnaire-R6)". This idea was also supported by Respondent-9 (R9) reiterating his main duties and authority as a language assistant as in the following quotation.

My main duties as a language assistant are to make a lesson plan and prepare relevant teaching media for the teaching and learning process. I am also given an authority to handle the class by myself. Therefore, I have to prepare the teaching materials comprehensively from the selection of materials, delivery of the materials to the class, and evaluation of the students' achievement (Interview-R9).

It is not easy to take the great opportunities for the Indonesian language to go international since there were some challenges that should be overcome by the language assistants to achieve the great mission in increasing the status of Indonesian from a national language into an international language. Some of the challenges, according to Sujana (2012), among others, were the unique ways of teaching Indonesian which were relatively different from that of the English teaching in terms of its teaching methodology, teaching materials, evaluation system, and administrative supporting systems. In term of the academic qualification, for instance, a native speaker of Indonesian who had earned a bachelor degree was not considered to have enough qualification to teach BIPA. In addition, considering that the targets and needs of the BIPA learners were different from one to another, the professional development of BIPA teachers and the increasing needs of better competences would never come to an end. Often times, misperception happened due to differences of cultures (Sujana, 2012).

Professional competence refers to the mastery of knowledge or skills that include the ability to choose and know the right choices. On the other hand, the demand for BIPA teachers was at least two languages needed to be their fields of mastery, namely Indonesian as the target language and native language of the BIPA learners, in this particular case was English, the language spoken by Australian. In this particular case, in her response to the questionnaire, Respondent-13 (R13) says:

As an Indonesian language assistant I have to speak Indonesian to the students in classes, however, I need to speak English to colleagues in schools, principals, and parents. In some occasions, I also speak English to students in some informal situations (Questionnaire-R13).

While in terms of the pedagogical competence, it was reflected in the ability of teachers to carry out language learning including the skills in selecting teaching materials, learning strategies and assessment tools. In the BIPA class, for instance, the ability of teachers to package learning greatly helps foreign speaking students to achieve their learning goals. With regard to the pedagogical competence, for instance, Idris (1999) further suggests that there are several principles to apply in BIPA class, namely: (1) the teacher must speak to all learners in Indonesian (not to talk only to learners who are most fluent in Indonesian); (2) the teacher uses Indonesian as the language of instruction in the teaching and learning process; and (3) the teacher introduces learners in private with native speakers or through videos and provides motivation to learners who want to use Indonesian outside the classroom independently. For the above reasons, therefore, the recruitment and selection process is focused on the graduates of the Faculty of Language and Literature Education of UPI who hold educational and pedagogical background to be the language assistants in this particular program. 


\section{Discussion}

As prospective Indonesian language assistants (BIPA teachers), the candidates are required to show their proficiency in Indonesian language through taking a proficiency test known as Uji Kemahiran Berbahasa Indonesia (UKBI) which is also used as a reference for teachers to evaluate their proficiency level (Nugraheni, 2015). For instance, in the case of Mediyawati, et. al. (2019), the UKBI was used as a reference to develop learning materials for foreign workers of the IFL business communication. Similarly, Hyun (2015) shares the importance of the Indonesian linguistic competence requiring the BIPA teachers to have an Indonesian language proficiency test certification with a level of achievement commonly set by the language center. This requirement is considered reasonable since in the teaching practices, in writing skill for instance, BIPA teachers are faced with learners encountering a great number of linguistic errors in their Indonesian writings, i.e. spelling errors, morphological errors, syntactic errors, and lexical errors (Darmayani, Artawa, \& Satyawati, 2018).

Likewise, when the learners are expressing something in their speaking practices, they are supposed to choose the right vocabulary to represent their ideas based on the relevant contexts (Hyun, 2015) and to use appropriate preposition, relevant conjunctions, and logical sentences without ambiguities (Yahya, Andayani, $\&$ Saddhono, 2018). In addition, Said (2010) has also identified another typical phenomenon that Indonesian language learners found difficulties and problems in making collocations through making negative transfers from English as their mother tongue to Indonesian. These can be solved by the teachers when they have been certified indicating their proficiency levels resulted from the proficiency test covering overall materials in the teaching of Indonesian for foreign speakers. Therefore, DET as the UPI's partner in this particular collaboration has clearly mentioned that the candidates of the Indonesian language assistants are native Indonesian speakers who have recently completed their relevant education studies at the undergraduate program (DET, 2018).

Considering the above complexities of the required proficiency and materials to be presented to the students, Respondent-1 (R1) reminds all teachers to use relevant contexts to deliver their materials to the students so that their teaching and learning activities will be meaningful to students. She shares her experiences to build contextual teachings in her Indonesian classes as in the following.

I introduce a becak (pedicap) and andong (carriage) to my students about a traditional means of transportation and kinds of Indonesian foods in a cooking class, i.e. nasi padang (Padang food), nasi goreng (fried rice), and gudeg, or through visiting any of the available Indonesian restaurants in the city, and puppets show through introducing the students with some characters of the puppets when there is a special show (Interview-Rl).

The candidates of the language assistants are also required to have sufficient knowledge and skills in the Indonesian arts and cultures and to have the cultural knowledge and skills in the targeted country. These requirements should also be interpreted into the practices of BIPA teaching. Koentajaraningrat (1991, cited in Ruskhan, 2007) identify seven cultural aspects to use in the BIPA teaching, i.e. equipment system and life facilities, employment system, community system, language, arts, knowledge system, and religious system. Another consideration in providing priority materials to be included in BIPA teaching, according to Hyun (2015), is the provision of guidelines for the cultural knowledge. Insufficient knowledge and understanding of Indonesian cultures, therefore, will give consequences to the learners to understand the richness of Indonesian people with their cultural varieties (Ruskhan, 2007). Gusnawaty \& Nurwati (2019) reiterate the importance of moral values, i.e. speech politeness, in a teaching model internalizing the Indonesian local cultures.

In response to cultural phenomenon, the cultural problems experienced by BIPA learners, Suyitno, Susanto, Kamal, \& Fawzi(2017)reiterate the importance of using authentic Indonesian cultures for the BIPA teaching materials, i.e. real community events, newspapers publication, news on televisions, cultural programs on radios, menus in restaurants, and relevant information in the advertisements. In addition, processes of 
obtaining cultural knowledge and skills would be very relevant to get themoutside the classrooms, i.e. through watching cultural performances, i.e. puppets show; and witnessing cultural ceremonies, i.e. weddings, funerals (Suyitno, et. al., 2017).

With regards to the exploration of Indonesian traditional arts and cultures, Respondent-5 shared her idea to learn numbers through the use of a traditional game called "Congklak" played by at least two players where their essential point of playing congklak is to collect as many congklak seeds as possible to win the game through her words, "I invite my students to play congklak as the media to learn numbers in Indonesian language and practice how to count them in practical ways (Interview$R 5)$ ". On the other occasions, R5 also introduces the richness of Indonesian arts and cultures through art performance by showing her own skills in performing Indonesian traditional dances, i.e. tari merak (peacock dance), tari jaipong (jaipong dance), and tari saman (saman dance) (Questionnaire-R5).

The materials of BIPA teaching, teaching methods and classroom management are formulated and designed based on the standardized curriculum that has been agreed by related parties who are responsible for the quality development of BIPA. The absence of a national standardized BIPA curriculum has been successfully responded by the Language Agency in Jakarta to formulate the standardized competences to develop a standardized curriculum. These competence standards are referred by the related parties to define the relevant competences for BIPA graduates through the involvement of national BIPA experts to adopt the standardized European language framework, Common European Framework of Reference (CEFR), as their reference to develop the framework (Aryawan, Pamungkas, \& Sonhadji, 2017).

With regard to the consideration of frameworks in the formulation of BIPA materials, there are two other principles to ponder, i.e. authenticity of learning materials selected by the teachers; and the use of a communicative language addressing real things (realia, not fictitious) in students' conversations (Suyitno, et. al., 2017). Then, the frameworks should also be formulated based on the needs of learners
(Gajewski, 2018) and these are presented referring to the level of their achievements from beginner to advanced level (Saputro \& Arikunto, 2018; Yahya, et. al., 2018). In addition, Saddhono (2016) also reiterates the importance of providing more attention and deeper investigation on BIPA management, teaching staffs, and teaching materials.

Finally, after the completion of their duties as Indonesian language assistants in Victorian schools, Australia, as the alumni of this program, they are also demanded to show their commitments to provide continued supports to UPI for the better development of this university, i.e. the development of BIPA in different faculties and units and in the language centre of UPI, for instance, to teach BIPA in more professional ways to achieve quality BIPA teaching at UPI. However, this condition is not a part of the programs specifically designed by UPI to invite the alumni to have a regular meeting among the BIPA teachers. Their employment at UPI has not been clearly defined and most of them do not even contact any one of the language assistants to another. Ideally, they join UPI to develop BIPA program at the university. Some of the relevant solutions that might be offered to achieve a professional BIPA program are undertaken through the formulation of clear curriculum and syllabus, the provision of comprehensive and systematic teaching materials, the supply of quality humanresources, particularly the teachers, through adequate trainings and workshops, certification program, the teaching of BIPA in a study program and even the opening of BIPA as a study program, and the improvement of service system and program administration. The synergy of these BIPA program organizations will result in better practices and more professional services (Sujana, 2012).

\section{CONCLUSION}

Universitas Pendidikan Indonesia has been implementing an Indonesian language assistant program to Victorian schools, Australia in collaboration with the Department of Education and Training, Victoria, Australia. The process of recruitment for the Indonesian language assistants from UPI has several stages. Each of the stages has its own purpose to select the best candidates required by both UPI and DET. Each of the selection processes is expected 
to comprehensively explore the overall skills and competences of the candidates. The main skills and competences required for the language assistants are the Indonesian language and English proficiency and these are then supported by cultural knowledge and skills of both Indonesian and that of the targeted cultures, Australian and other supporting skills, i.e. communication and self-management. The knowledge of cultures, particularly the Indonesian traditional cultures are needed by the language assistants to provide the students with some relevant and adequate contexts on the materials taught in Indonesian language classes. However, for the sustainability of this program, the system of recruitment and selection process should be continuously improved in order to select the best quality candidates for the coming years. Further research will be focused on the implementation of teaching practices experienced by the Indonesian language assistants and how they self-manage themselves in succeeding the language assistants program in Victorian schools.

\section{ACKNOWLEDGEMENT}

Researchers would like to extend our highest appreciation and sincere gratitudes to the Ministry of Research, Technology, and Higher Education and Universitas Pendidikan Indonesia (UPI) for their funding supports for the completion of this research.

\section{REFERENCES}

Aryawan, F. N., Pamungkas, A. H., \& Sonhadji, A. (2017). Impacts of BIPA teaching policy on capacity building of course and training system. Journal of Nonformal Education, 3(2), 164-178. doi:10.15294/ jne.v3i2.10952.

Azizah, R. F., Widodo, H. S., \& Lestari, I. (2012). Pembelajaran Bahasa Indonesia bagi Penutur Asing (BIPA) Program CLS (Critical Language Scholarship) di Fakultas Sastra Universitas Negeri Malang. Retrieved from https://www. jurnal-online.um.ac.id.

Creswell, J. W., \& Poth, C. N. (2018). Qualitative inquiry and research design: Choosing among five approaches (4th ed.). Los Angeles: SAGE Publications, Inc.
Darmayani, N. W. S., Artawa, K., \& Satyawati, M. S. (2018). Linguistic errors of using Indonesian in foreign learners' writings. Kulturistik: Jurnal Bahasa \& Budaya, 2(1), 92-102. doi:10.22225/kulturistik.2.1.679.

DEEWR. Department of Education, Employment and Workplace Relations, Government of Australia. (2010). The current State of Chinese, Indonesian, Japanese and Korean Language Education in Australian schools: Four languages, four stories. Carlton South, Victoria: Education Services Australia.

DET. Department of Education and Training, Victoria, Australia. Retrieved from https://www.education.vic.gov.au/ school/teachers/teachingresources/ discipline/ languages/manage/Pages/ languageassistant.aspx.

Dodiangga, D. (2017, July). Guru lulusan UPI berkualitas. Retrieved from: http://berita. upi.edu/guru-lulusan-upi-berkualitas/.

Gajewski, D. M. (2018). Evaluasi program pengajaran BIPA: Suatu perspektif pelajar asing. Prosiding SAGA, 1(1), 327-334.

Gay, L. R., Mills, G. E., \& Airasian, P. (2006). Educational research: Competencies for analysis and applications ( $8^{\text {th }}$ ed.). New Jersey, NJ: Pearson Education, Inc.

Gusnawaty, G., \& Nurwati, A. (2019). A learning model of Bahasa Indonesia as a foreign language based on local intercultural politeness. Cakrawala Pendidikan, 38(1), 141-155. doi:10.21831/cp.v38i1.23022.

Hyun, P. J. (2015). Potensi dan tantangan bahasa Indonesia menuju bahasa internasional. Jurnal Sosioteknologi, 14(1), 12-20. doi:10.5614\%2Fsostek.itbj.2015.14.1.2.

Idris, N. S. (1999, October). Ragam media dalam pembelajaran BIPA. Paper presented at the KIPBIPA III, Universitas Pendidikan Indonesia, Bandung.

Mediyawati, N., Lustyantie, N., \& Emzir. (2019). Media: Designing a model of IFL learning 
materials for foreign workers. Cakrawala Pendidikan, 38(1), 75-89. doi:10.21831/ cp.v38i1.22245.

Memorandum of Understanding (MoU) between Universitas Pendidikan Indonesia (UPI), Monash University, Australia, and Department of Education and Training (DET), Victoria, Australia, 2004.

Memorandum of Understanding (MoU) between Universitas Pendidikan Indonesia (UPI), Monash University, Australia, and Department of Education and Early Childhood Development (DEECD), Victoria, Australia, 2010.

Memorandum of Understanding (MoU) between Universitas Pendidikan Indonesia (UPI) and Department of Education and Training (DET), Victoria, Australia, 2017.

Muliastuti, L. (2016). BIPA pendukung internasionalisasi Bahasa Indonesia. Retrieved from http://fkip.untidar.ac.id/.

Nugraheni, A. S. (2015). Pengembangan program profesionalisme dosen pengajar Bahasa Indonesia untuk Penutur Asing (BIPA) di ASEAN. Al-Bidayah: Jurnal Pendidikan Dasar Islam, 7(1), 89-101.

OEIR. Office of International Education and Relations, Universitas Pendidikan Indonesia. (2011-2018). Laporan guru bantu Bahasa Indonesia bagi Penutur Asing (Bipa) Universitas Pendidikan Indonesia di Victoria, Australia. Bandung: Unpublished Institutional Report.

RoI, Law 2015 No. 14 Article 1 (Paragraph 1), the Main Task of Teachers.

RoI, Ministrial Regulation of National Education 2007 No. 16, the Academic Qualification Standards and Teacher Competence.

Ruskhan, A. G. (2007). Pemanfaatan keberagaman budaya Indonesia dalam pengajaran Bahasa Indonesia bagi Penutur Asing (BIPA). SAWERIGADING, 16(1), 81-88. doi:10.26499/sawer.v16i1.298.
Saddhono, K. (2016). Teaching Indonesian as foreign language( in Indonesia: Impact of professional managerial on process and student outcomes. Proceedings of the 6th International Conference on Educational, Management, Administration and Leadership Vol. 14 (pp.263-266). Bandung: Atlantis Press. doi:10.2991/ icemal-16.2016.54.

Said, M. (2010). Ketidaklaziman kolokasi pembelajar BIPA dan implikasinya terhadap pembelajaran bahasa. Cakrawala Pendidikan, 29(2),204-213. doi:10.21831/ cp.v2i2.340.

Saputro, E. P., \& Arikunto, S. (2018). Keefektifan manajemen program pembelajaran BIPA (Bahasa Indonesia bagi Penutur Asing) di kota Yogyakarta. Jurnal Akuntabilitas Manajemen Pendidikan, 6(1), 123-138. doi:10.21831/amp.v6i1.8066.

Sujana, I. M. (2012, September). Program Bahasa Indonesia untuk Penutur Asing (BIPA): Peluang, tantangan dan solusi. Paper presented at the International Seminar entitled "Menimang Bahasa Membangun Bangsa", Lombok, West Nusa Tenggara.

Suyitno, I. (2007). Pengembangan bahan ajar Bahasa Indonesia untuk Penutur Asing (BIPA) berdasarkan hasil analisis kebutuhan belajar. Wacana, Journal of the Humanities of Indonesia, 9(1), 62-78.

Suyitno, I., Susanto, G., Kamal, M., \& Fawzi, A. (2017). Teaching materials and techniques needed by foreign students in learning Bahasa Indonesia. ISLLAC: Journal of Intensive Studies on Language, Literature, Art, and Culture, 1(1), 52-70. doi:10.17977/um006v1i12017p052.

Yahya, M., Andayani, \& Saddhono, K. (2018). Tendensi kesalahan sintaksis bahasa tulis pembelajar Bahasa Indonesia bagi Penutur Asing (BIPA). Sukma: Jurnal Pendidikan, 2(1), 137-166. doi:10.32533/02106(2018). 